jumeaux (Zwillingszapfen)" and the sense in which Cajal used "spongioblast", and so on.

A translation of Greeff's introduction is included. The references are more conveniently placed at the end of the chapters instead of, as in the original, in footnotes. Useful additions are a list of Cajal's papers on the visual system of vertebrates and invertebrates; a name and a subject index, so that one can quickly glean a summary of Cajal's commentaries on various authors, other animals and types of cells. The original plates are very well reproduced considering the difficulties of copying and reducing the size of the figures. Compared with my copy of the 1894 edition there is, however, an occasional slight loss of definition of some of the finer processes of the cells. Ironically this sometimes makes them more closely resemble what may at first be seen in a Golgi preparation.

\section{B. B. BOYCOTT}

\section{Dartians to Martians}

Not from the Apes. By Björn Kurtén. Pp. viii +183 . (Victor Gollancz: London, June 1972.) £1.75.

BJÖRN KURTÉN already has an established reputation as the author of readable books on vertebrate palaentology, such as The Age of the Dinosaurs and Pleistocene Mammals of Europe. In Not from the Apes, he has turned his hand to the vexed question of human evolution. He attempts to explain to the layman a subject which is still the centre of animated discussion among the experts, who are generally reluctant to write such books at this stage of research. This is why African Genesis, which was written by a former playwright (Robert Ardrey), was eagerly read by many who were impatient to read any kind of summary of the discussion of human origins. There is no justification, however, for "popularizing" material not yet established as scientifically sound. It is therefore unfortunate that Kurtén should have based his book on the poorly supported hypothesis that the ancestors of man and the apes separated more than 35 million years ago. This flaw greatly reduces the value of an otherwise enjoyable book which quite neatly summarizes human evolution from the Australopithecines ("Dartians") onwards. The reader is largely presented with opinions, not facts, and this cannot be justified merely as a means of avoiding complexity.

It rarely emerges from the text that the author's opinions are based on a handful of fossil fragments of Propliopithecus and Ramapithecus which are supposed to represent $30-35$ million years of human evolution before Australopithecus. A sense of proportion could have been kept by illustrating all of these fragments on one page. Such is the "historical evidence" of which Kurtén states: "I am afraid that we cannot dispense with key characteristics; fortunately the teeth give us all the necessary ones as far as apes and man are concerned." Kurtén does admit, however, that the scientist "cannot reconstruct a hitherto unknown animal on the basis of a single tooth or even the whole tooth row... . This is the situation with Ramapithecus." One of the few illustrations in this book shows a "reconstruction" of the entire skull of Ramapithecus!

Kurten is, of course, aware that the
African great apes and man show remarkable similarities in chromosome and protein structure; but he concludes that these are due to parallel evolution. He does not consider the possibility that some of the morphological similarities between Propliopithecus, Ramapithecus, Australopithecus and Homo might be parallel developments. Further, Kurtén overlooks the fact that it is very unlikely that similar amino-acid sequences will arise independently in two animal species, and that such changes are accessible to mathematical treatment. The possibilities of parallel evolution in mammalian dental and cranial anatomy can be estimated only crudely and subjectively. Some serologists-such as Sarich-have admittedly taken the opposite view that the fossil record can be largely ignored when constructing evolutionary trees, and have concluded that the ancestors of African apes and man separated only five million years ago. This view is just as reprehensible as the claim that the fossils can tell us all we need to know; neither approach is desirable.

Let us hope that the readers of this book, on seeing the section suggesting that man might develop as a new species on Mars, will realize that Kurtén should not be taken seriously.

\section{R. D. Marten}

\section{Addendum}

IN Dr Cornwall's review of the Atlas of Animal Bones for Prehistorians, Archeologists and Quaternary Geologists (Bilingual Bones, Nature, 238, 474; 1972), the name of the author, Elizabeth Schmid, was unfortunately omitted. We apologize for this oversight.

\section{HOW TO BUY NATURE}

Volumes start in January, March, May, July, September and November, but subscriptions may begin at any time. The direct postal price per subscription is:

12 MONTHS * (52 issues per title)

\begin{tabular}{|c|c|c|}
\hline & $\begin{array}{c}\text { Surface mail } \\
\text { UK and } \\
\text { worldwide }\end{array}$ & $\begin{array}{l}\text { U.S.A. and } \\
\text { Canada }\end{array}$ \\
\hline Nature (Friday) & $£ 14$ & $\$ 48$ \\
\hline $\begin{array}{l}\text { Nature }+ \\
\text { Nature Physical Science }\end{array}$ & $£ 24$ & $\$ 83$ \\
\hline $\begin{array}{l}\text { Nature + } \\
\text { Nature New Biology }\end{array}$ & $£ 24$ & $\$ 83$ \\
\hline All three editions & $£ 29.50$ & $\$ 108$ \\
\hline Annual Index & $\mathbf{E 1}$ & $\$ 3$ \\
\hline
\end{tabular}

* Rates for shorter periods pro rata (minimum three months) (Charge for delivery by air mail on application)
Editorial, Advertising and Publishing Offices of NATURE

MACMILLAN JOURNALS LIMITED

4 LITTLE ESSEX STREET, LONDON WC2R 3LF

Telephone Number: $01-836$ 6633. Telegrams: Phusis London WC2R 3LF Telex 262024

MACMILLAN JOURNALS LIMITED

711 NATIONAL PRESS BUILDING

WASHINGTON DC 20004

Telephone Number: 202-737 2355. Telex 64280

International Advertisement Manager

PETER R. KAVANAGH

MACMILLAN JOURNALS LIMITED

4 UTTLE ESSEX STREET, LONDON WC2R 3LF

Telephone Numbers: UK 01-836 6633. USA 202-737 2355

Subscription Department

MACMILLAN JOURNALS LIMITED

BRUNEL ROAD, BASINGSTOKE, HANTS

Telephone Number: Basingstoke 29242

Classified advertisements

T. G SCOTT \& SON, LIMITED

1 CLEMENT'S INN, LONDON WC2A 2ED

Telephone Number: 01-242 6264/01-405 4743

Telegrams: Textualist London WC2A 2ED

Registered as a newspaper at the Post Office

Copyright (C) Macmillan Journals Limited, October 271972 